\title{
Reproductive Health Matters
}

\section{Susan Quilliam}

Writer, Broadcaster, Consultant and Trainer, Cambridge, UK

Correspondence to Ms Susan Quilliam; susan@susanquilliam.com; http://www.susanquilliam.com

Received 20 October 2013 Accepted 20 October 2013
To cite: Quilliam S. J Fam Plann Reprod Health Care 2014;40:71-72.

\section{HOW AND WHY DID YOU LAUNCH REPRODUCTIVE HEALTH MATTERS?}

In 1993, a group of advocates in the arena of women's reproductive health and rights realised that there were very few journals existing in the field. Further, most of the existing journals focused on clinical, population and family planning issues, and reported only quantitative research.

The original group - including founding editor, Marge Berer, and founding co-editor, TK Sundari Ravindran - identified a need for a women-centred and global viewpoint on the issues, along with a combined public health/rights perspective on laws, policy and service delivery.

What emerged was Reproductive Health Matters: we now cover male as well as female health issues, welcome viewpoints from many disciplines, and aim to take a completely global perspective.

\section{WHO READS REPRODUCTIVE HEALTH MATTERS?}

We are read by a variety of those involved in or interested in sexual and reproductive health and rights worldwide, including advocates, activists, health workers, health agencies, researchers, service providers, political negotiators, and those involved in developing human rights treaties.

We offer the journal on subscription and also distribute copies at relevant conferences. We are particularly committed to making sure that the journal is read even in resource-constrained settings, so we offer free subscriptions in certain areas and to certain groups. Indeed 90\% of our subscribers are from the global south and receive the journal free.

Beginning in 1996, the journal has been translated; we now publish versions in Arabic, Chinese, French, Hindi, Portuguese, Russian and Spanish.

\section{WHAT'S THE CURRENT FORMAT?}

We publish the journal twice yearly. Each issue includes commentaries, coverage of current policy issues, book reviews, news, information summaries and a core group of papers on a main theme. Recent such themes have included: repoliticising sexual and reproductive health and rights; maternal health and morbidity; young people, sex and relationships. Our supporting website (http://www. rhmjournal.org.uk) also includes a section for authors on writing for publication.

Over the years we have published 42 journal issues, four supplements and two books; over 350000 copies of the journal have been published and one million pages downloaded. We also blog and tweet.

\section{WHAT'S YOUR STAFF STRUCTURE?}

Currently, our in-house team comprises an editor, an online editor, a news editor, a promotion and administration manager and a finance officer. We outsource design, typesetting and printing, using the publishing house Elsevier for distribution of print copy; we further disseminate on the Elsevier website as well as on Science Direct and HINARI. For foreign editions we use translators in each home market and our advisory board/trustees comprise 46 members based in more than 15 countries.

Our authors and reviewers are drawn from practitioners in 180 countries worldwide. We are particularly committed to offering sustained support to our authors, and to making sure that neither language barriers nor lack of experience in writing for publication hinders the messages that our authors want to disseminate.

\section{WHAT MAKES YOU DIFFERENT FROM OTHER JOURNALS IN THE \\ REPRODUCTIVE HEALTH FIELD?}

We cover controversial issues that no one else has touched, and we help to put some topics onto the agenda for the first time: two key examples would be cosmetic surgery seen from a feminist perspective, and the criminalisation of sexual and reproductive health services. 
We have also exposed major problems such as the role of privatisation of services and its effects on the lack of equity of access to care and treatment. We further explore the links between HIV and sexual and reproductive health and rights, and cover abortion issues globally more than any other journal. We are also the only international health journal published in eight languages.

\section{DO YOU RUN SPECIAL EVENTS?}

Over the past decades, we have organised a number of conferences on health sector reform, on abortion, on condoms, and on repoliticising sexual and reproductive health and rights.

\section{WHAT'S BEEN YOUR BIGGEST PROBLEM OVER THE YEARS?}

Although we have gained many donors and kept to our budget, the funding we attract has always been short term and this has hit harder as we have grown. As a result, we are now only able to fund a smaller staff than we need, and have had to be more cautious than we would like about expanding the number of papers we publish and our role as a knowledge platform.

\section{WHAT'S BEEN YOUR BIGGEST TRIUMPH?}

We are proud of the fact that we have put womencentred perspectives on the global map and raised the profile of sexual and reproductive health and rights for both genders. We have managed to be an independent entity for 21 years so far. We have also mentored many young and new authors, prioritising contributions from authors from the global south before that was common. We are pleased to say that many authors who first published in Reproductive Health Matters are now submitting papers to other journals too, and that authors from the global south are now more frequently published than before.

\section{WHAT'S YOUR BIGGEST WORRY AND YOUR BIGGEST HOPE FOR THE FUTURE?}

The proliferation of journals in the past 6-8 years, plus all the recent technological changes, has meant we are having to work hard to keep up with the pace of change in a context where funding is tight, even as we are seeking to reach a wider audience (e.g. through social media) and increase the impact of the information we publish in our field.

Our biggest hope and our current mission is to bring the journal into the 21st century, continuing our work but expanding our ability to globally transmit knowledge about, and to influence the direction of, advocacy, policy and debate on sexual and reproductive health.

\section{WHAT WOULD BE YOUR 'LAST WORD' TO JOURNAL READERS?}

Our mission is not just to publish papers but also to contribute to making change happen and the improvement of sexual and reproductive health and rights around the world.

\section{FURTHER INFORMATION}

$\begin{array}{ll}\text { Who: } & \text { Reproductive Health Matters } \\ \text { Where: } & \begin{array}{l}\text { 444 Highgate Studios, 53-79 Highgate } \\ \text { Road, London NW5 1TL, UK }\end{array} \\ \text { Contact: } & \begin{array}{l}\text { Tel }+44 \quad \text { (0) } 20 \quad 7267 \quad 6567 . \quad \text { E-mail: } \\ \text { info@rhmjournal.org.uk }\end{array} \\ \text { Website: } & \begin{array}{l}\text { www.rhmjournal.org.uk (RHM) or www. } \\ \text { rhm-elsevier.com (Elsevier) }\end{array} \\ \text { Publications: } & \text { Back issues, supplements and books from } \\ & \begin{array}{l}\text { 1993-2012 are available from the website } \\ \text { and in print on request; themed collections } \\ \text { of papers are also available on CD. }\end{array}\end{array}$

\section{Competing interests None.}

Provenance and peer review Commissioned; internally peer reviewed.

Editor's note This article is one in a series of occasional articles on key health organisations worldwide. The Journal would be pleased to hear from other organisations, particularly those based outside the UK, which would like to be similarly profiled. 